\title{
Responses of ammonia-oxidizing bacteria and archaea to nitrogen fertilization and precipitation increment in a typical temperate steppe in Inner Mongolia
}

\author{
Yongliang Chen ${ }^{\mathrm{a}}$, Zhuwen $\mathrm{Xu}^{\mathrm{b}}$, Hangwei $\mathrm{Hu}^{\mathrm{a}}$, Yajun $\mathrm{Hu}^{\mathrm{a}}$, Zhipeng Hao ${ }^{\mathrm{a}}$, Yong Jiang ${ }^{\mathrm{b}}$, \\ Baodong Chen ${ }^{\mathrm{a}, *}$ \\ a State Key Laboratory of Urban and Regional Ecology, Research Center for Eco-Environmental Sciences, Chinese Academy of Sciences, Beijing 100085, China \\ b State Key Laboratory of Forest and Soil Ecology, Institute of Applied Ecology, Chinese Academy of Sciences, Shenyang 110016, China
}

\section{A R T I C L E I N F O}

\section{Article history:}

Received 7 October 2012

Received in revised form 5 March 2013

Accepted 14 March 2013

\section{Keywords:}

Ammonia-oxidizing archaea

Ammonia-oxidizing bacteria

Potential nitrification rate

Nitrogen deposition

Precipitation increment

Temperate steppe

\begin{abstract}
A B S T R A C T
As the first and rate-limiting step of nitrification, ammonia oxidation can be realized either by ammoniaoxidizing bacteria (AOB) or archaea (AOA). However, the key factors driving the abundance, community structure and activity of ammonia oxidizers are still unclear, and the relative importance of AOA and AOB in ammonia oxidation is unresolved. In the present study, we examined the effects of long-term (6 years) nitrogen $(\mathrm{N})$ addition and simulated precipitation increment on the abundance and community composition of AOA and $\mathrm{AOB}$ based on a field trial in a typical temperate steppe of northern China. We used combined approaches of quantitative PCR, terminal-restriction fragment length polymorphism (T-RFLP) and clone library analyses of $a m o A$ genes. The study objective was to determine (1) AOA and AOB diversity and activity in response to $\mathrm{N}$ addition and increased precipitation and (2) the relative contributions of $A O A$ and $A O B$ to soil ammonia oxidation in the typical temperate steppe. The results showed that the potential nitrification rate (PNR) increased with $\mathrm{N}$ addition, but decreased with increased precipitation. Both $\mathrm{N}$ addition and increased precipitation significantly increased AOB but not AOA abundance, and a significant correlation was only observed between PNR and AOB amoA gene copies. The T-RFLP analysis showed that both $\mathrm{N}$ and precipitation were key factors in shaping the composition of AOB, while AOA were only marginally influenced. Phylogenetic analysis indicated that all AOA clones fell within the soil and sediment lineage while all AOB clones fell within the Nitrosospira. The study suggested that AOA and $A O B$ had distinct physiological characteristics and ecological niches. AOB were shown to be more sensitive to $\mathrm{N}$ and precipitation than $\mathrm{AOA}$, and the ammonia oxidation process was therefore supposed to be mainly driven by AOB in this temperate steppe.
\end{abstract}

(c) 2013 Elsevier B.V. All rights reserved.

\section{Introduction}

Anthropogenic disturbance and global climate change are greatly affecting ecosystems worldwide by ways such as widespread nitrogen $(\mathrm{N})$ deposition and changing precipitation regimes (IPCC, 2007). Increase in global atmospheric $\mathrm{N}$ deposition is caused by anthropogenic activities, including increasing $\mathrm{N}$ fertilizer application in agricultural ecosystems (Guo et al., 2010) and fossil fuel combustion. Nitrogen deposition can significantly influence the global $\mathrm{N}$ cycle, and lead to increased plant productivity and reduced plant species richness in grassland (Gough et al., 2000; Stevens et al., 2004).

\footnotetext{
* Corresponding author. Tel.: +8610 62849068

E-mail address: bdchen@rcees.ac.cn (B. Chen)
}

On the other hand, the precipitation regimes are predicted to change at both global and regional scales (Dore, 2005; Ni and Zhang, 2000), which also brings fundamental influences on terrestrial ecosystems, especially in arid or semi-arid areas where water supply is extremely limited (Hooper and Johnson, 1999). Manipulative experiments have shown that increased precipitation can stimulate species richness in a temperate steppe (Yang et al., 2011) and enhance biodiversity in annual grassland (Zavaleta et al., 2003). Because both $\mathrm{N}$ and water are key factors limiting plant growth in terrestrial ecosystems (Hooper and Johnson, 1999; Xia and Wan, 2008), changes in their availability will have profound influences on ecosystem processes, including underground microorganism functions.

Nitrification, the oxidation of ammonia to nitrate via nitrite, is a key process in soil $\mathrm{N}$ cycling. The first and rate-limiting step of nitrification, oxidation of ammonia to nitrite, is traditionally believed to be primarily performed by autotrophic ammoniaoxidizing bacteria (AOB) within the $\beta$ - and $\gamma$-subclasses of the 
Proteobacteria. Recently, metagenomic analyses has revealed that a novel archaeal group also possesses the homologs of an AOB-like ammonia monooxygenase gene (Venter et al., 2004; Treusch et al., 2005), and the first isolated mesophilic crenarchaeon, Nitrosopumilus maritimus, confirmed the capacity of ammonia-oxidizing archaea (AOA) to oxidize ammonia (Könneke et al., 2005). Based on identifiable distinction in phylogenetic analysis of ribosomal protein encoding genes and some protein-coding genes, the archaeal ammonia oxidizers were separated from the Crenarchaeota into a new phylum, Thaumarchaeota (Brochier-Armanet et al., 2008).

Recent genomic studies of $N$. maritimus have revealed remarkable differences between thaumarchaeal ammonia oxidation and the analogous process in AOB (Walker et al., 2010). The higher affinity of archaeal AMO than bacterial AMO for ammonia offered a significant advantage for thaumarchaea in nutrient-poor environments (Martens-Habbena et al., 2009; Martens-Habbena and Stahl, 2011). Recent studies have shown that AOA possess the genetic capacity to potentially utilize organic carbon, and in some cases also small organic molecules (Hallam et al., 2006; Blainey et al., 2011; Tourna et al., 2011). Such mixotrophic characteristics are also detected in AOB strains (He et al., 2012).

Archaeal ammonia oxidizers are ubiquitous in various ecosystems (Venter et al., 2004; Treusch et al., 2005; Leininger et al., 2006; He et al., 2007; Nicol et al., 2008), and dominate in abundance over their bacterial counterparts in multiple environments, particularly in soils (Leininger et al., 2006; Nicol et al., 2008; Zhang et al., 2010). These findings suggest that AOA may play a more significant, but previously unrecognized role than $A O B$ in nitrification. However, understanding of the relative importance of $A O A$ and $A O B$ in ammonia oxidation remains very limited. In a number of soil microcosm studies, AOA were found to mainly control microbial ammonia oxidation (Offre et al., 2009; Gubry-Rangin et al., 2010; Zhang et al., 2010, 2012). However, AOB were also observed to dominate ammonia oxidation in microcosms supplied with high levels of $\mathrm{N}$ fertilizers (Di et al., 2009; Jia and Conrad, 2009; Xia et al., 2011). So far, many studies have indicated that AOB growth can benefit from high ammonia availability, whereas AOA are greatly favored at low ammonia concentrations. To elucidate the diversity and function of ammonia oxidizers, it is critically important to reveal their characteristics and the edaphic physico-chemical factors driving the ecological fitness and niche separation of AOA and AOB in various environments.

Numerous studies have shown the changes in abundance and community structure of AOA and AOB in response to various environmental factors, including $\mathrm{N}$ fertilization regimes (Shen et al., 2008, 2011; Di et al., 2009, 2010). Long-term N fertilization had significant impacts on AOB but not AOA abundance and composition in an alkaline sandy soil (Shen et al., 2008). In N-rich grassland soils, AOB abundance and activity increased whereas the AOA abundance and activity remain unchanged in response to $\mathrm{N}$ additions (Di et al., 2009). Similarly, in a semi-arid grassland, long-term $\mathrm{N}$ loading exerted significant influences on abundance and composition of AOB but not AOA (Shen et al., 2011). In addition, soil moisture also affects the main processes of the $\mathrm{N}$ cycle, such as mineralization, denitrification, $\mathrm{N}$ fixation, and particularly nitrification (Norton and Stark, 2011). A number of studies have shown considerable soil moisture effects on the abundance and community structure of ammonia oxidizers (Singh and Kashyap, 2006; Avrahami and Bohannan, 2007; Gleeson et al., 2008, 2010; Szukics et al., 2010, 2012). In a microcosm study, the water-filled pore space (WFPS) in soil altered the AOA and AOB community structure (Gleeson et al., 2010). However, the interactive effects of soil moisture and $\mathrm{N}$ fertilizers on the activity, abundance and community structure of ammonia oxidizers have so far not been examined.
In order to examine the potential effects of $\mathrm{N}$ deposition and changes in precipitation regime on ammonia oxidizers, a field experiment with a constant increase in precipitation and three $\mathrm{N}$ supply levels was established in the typical temperate steppe in Inner Mongolia in 2005. This temperate steppe is a typical vegetation type in the Eurasian continent, and has been reported to be highly sensitive to the climate change (Liu et al., 2009; Niu et al., 2008; Yang et al., 2011). It is predicted that the mean annual precipitation in the steppe will continue to increase in future (Ni and Zhang, 2000). Furthermore, N deposition in the North China Plain is also expected to increase continuously (Zhang et al., 2008). We collected soil samples from the experimental field in August 2010, and measured abundance, community composition and activity of $\mathrm{AOB}$ and $\mathrm{AOA}$ by molecular and chemical analyses. The study objective was to reveal (1) how AOA and AOB biodiversity and activity differ in response to $\mathrm{N}$ addition and increased precipitation, and (2) the relative contributions of AOA and AOB to soil ammonia oxidation in the steppe. The study will generate important implications for predicting the long-term responses of grassland ecosystems to global climate change.

\section{Materials and methods}

\subsection{Site description and soil sampling}

The experimental plots were established in a typical temperate steppe in Duolun County (E $116^{\circ} 17^{\prime} 20^{\prime \prime}, \mathrm{N} 42^{\circ} 2^{\prime} 29^{\prime \prime}$ ) in Inner Mongolia, China. This area was previously a pastoral zone with a temperate continental monsoon climate. Mean annual temperature (MAT) in the research area is $2.1^{\circ} \mathrm{C}$ with the mean monthly temperature ranging from $-17.5^{\circ} \mathrm{C}$ in January to $18.9^{\circ} \mathrm{C}$ in July. Mean annual precipitation (MAP) is $\sim 380 \mathrm{~mm}$, with $>80 \%$ of the precipitation occurring between June and September. The soil is classified as Haplic Calcisol according to the FAO classification. The experiment was established in 2005 with a split plot experiment design, including four replicate blocks, each containing six $8 \mathrm{~m} \times 8 \mathrm{~m}$ plots with a $1 \mathrm{~m}$ wide buffer zone. The six plots within each block were randomly assigned to the following treatments: N0 (control), N5 $\left(5 \mathrm{~g} \mathrm{~N} \mathrm{~m}^{-2} \mathrm{yr}^{-1}\right), \mathrm{N} 15\left(15 \mathrm{~g} \mathrm{~N} \mathrm{~m}^{-2} \mathrm{yr}^{-1}\right)$, PNO (precipitation increment only), PN5 (precipitation increment and $5 \mathrm{~g} \mathrm{~N} \mathrm{~m}^{-2} \mathrm{yr}^{-1}$ ) and PN15 (precipitation increment and $15 \mathrm{~g} \mathrm{~N} \mathrm{~m}^{-2} \mathrm{yr}^{-1}$ ). The $\mathrm{N}$ amendment was urea (applied twice, half in early May and the other half in late June). The precipitation increment plots received $15 \mathrm{~mm}$ of simulated precipitation weekly via sprinkling irrigation from June to August. A total of $180 \mathrm{~mm}$, equal to $\sim 50 \%$ of MAP in this study site, was performed during the growth season (15 mm per week for 12 weeks).

Soil samples were collected in August 2010. For each plot, five soil cores were randomly taken from the topsoil $(0-10 \mathrm{~cm})$ and then mixed to form one composite sample. All samples were placed in a standard ice box with a temperature of $\sim 0^{\circ} \mathrm{C}$ and transported to the laboratory within two days. Soil samples were passed through a $2.0 \mathrm{~mm}$ sieve and stored at $4{ }^{\circ} \mathrm{C}$ before soil chemical analysis, and $-80^{\circ} \mathrm{C}$ before DNA extraction.

\subsection{Soil chemical analysis and potential nitrification rate}

Soil samples were dried for $48 \mathrm{~h}$ at $105^{\circ} \mathrm{C}$ to measure soil water content. Soil pH was determined with a soil to water ratio of $1: 2.5$. Soil nitrate and ammonium were extracted with $2 \mathrm{M} \mathrm{KCl}$ (soil to water ratio of 1:5), and then measured with a continuous flow analyzer (SAN++, Skalar, Breda, Holland). Soil total N content and total carbon content were measured with an element analyzer (Vario EL III, Elementar, Hanau, Germany). Potential nitrification rate (PNR) was measured using the chlorate inhibition method (Kurola et al., 
2005). Briefly, $5.0 \mathrm{~g}$ of fresh soil was added to $50 \mathrm{ml}$ centrifuge tubes containing $20 \mathrm{ml}$ of phosphate buffer solution (PBS) $\left(\mathrm{gl}^{-1}\right.$ : $\mathrm{NaCl}, 8.0 ; \mathrm{KCl}, 0.2 ; \mathrm{Na}_{2} \mathrm{HPO}_{4}, 0.2 ; \mathrm{NaH}_{2} \mathrm{PO}_{4}, 0.2 ; \mathrm{pH} 7.4$ ) with $1 \mathrm{mM}$ $\left(\mathrm{NH}_{4}\right)_{2} \mathrm{SO}_{4}$. Potassium chlorate with a final concentration of $10 \mathrm{mM}$ was added to the tubes to inhibit nitrite oxidation. The suspension was incubated in a dark incubator at $25^{\circ} \mathrm{C}$ for $24 \mathrm{~h}$, after which nitrite was extracted with $5 \mathrm{ml}$ of $2 \mathrm{M} \mathrm{KCl}$ and determined spectrophotometrically at $540 \mathrm{~nm}$ with $N$-(1-naphthyl) ethylenediamine dihydrochloride.

\subsection{DNA extraction and quantitative PCR of amoA genes}

Soil DNA was extracted from $0.5 \mathrm{~g}$ of soil using the Fast DNA ${ }^{\circledR}$ SPIN Kit for Soil (Q BIOgene Inc., Carlsbad, CA, USA) according to the manufacturer's instructions. The extracted DNA was checked on a $1 \%$ agarose gel and the DNA concentration was assessed using a Nanodrop ${ }^{\circledR}$ ND-1000 UV-Vis Spectrophotometer (NanoDrop Technologies, Wilmington, DE, USA).

Primer pairs Arch-amoAF/Arch-amoAR (Francis et al., 2005) and amoA1F/amoA2R (Rotthauwe et al., 1997) were used for qPCR of AOA and AOB amoA genes as described by Zhang et al. (2012), respectively. The qPCR assays were performed on an iCycler iQ5 Thermocycler (Bio-Rad Laboratories, Hercules, CA, USA). Amplification was performed in $25 \mu \mathrm{l}$ reaction mixtures, including $12.5 \mu \mathrm{l}$ SYBR $^{\circledR}$ Premix Ex Taq ${ }^{\mathrm{TM}}$ (Takara Biotechnology, Dalian, China), $1 \mu \mathrm{l}$ bovine serum albumin $\left(25 \mathrm{mg} \mathrm{ml}^{-1}\right), 0.5 \mu$ l each primer $(10 \mu \mathrm{M})$, and $2 \mu$ l diluted DNA (1-10 ng) as a template. Product specificity was checked by melt curve analysis at the end of the PCR runs and visualization by agarose gel electrophoresis. A known copy number of plasmid DNA for AOA or AOB was used to generate a standard curve. For all assays, PCR efficiency was $90-100 \%$ and $r^{2}$ was 0.95-0.99.

\subsection{Terminal restriction fragment length polymorphism (T-RFLP)}

For T-RFLP analysis, the PCR amplification was performed using the same primer pairs as the qPCR assays described above, with each forward primer labeled with 6-carboxyfluorescein (FAM). The $25 \mu$ l PCR reactions contained $2.5 \mu \mathrm{l} 10 \times$ PCR buffer $\left(\mathrm{Mg}^{2+}\right.$

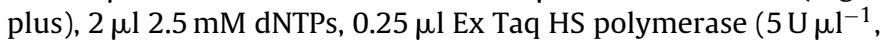
Takara Biotechnology, Dalian, China), $0.5 \mu$ l of each primer, and $2 \mu$ l diluted DNA template (1-10 ng). The PCR reaction was the same as that for the qPCR assays. PCR products were gel-purified with the Wizard ${ }^{\circledR}$ SV Gel and PCR Clean-Up Kit (Promega, San Luis Obispo, CA, USA) and then digested with the restriction enzyme FastDigest ${ }^{\circledR} \mathrm{Mbo}$ I (Takara Biotechnology, Dalian, China) at $37^{\circ} \mathrm{C}$ for $5 \mathrm{~min}$ and then at $65^{\circ} \mathrm{C}$ for $15 \mathrm{~min}$. The digested products were purified by ethanol precipitation and mixed with deionized formamide and then determined with an Abi Prism ${ }^{\circledR}$ 3130XL Genetic Analyzer (Applied Biosystems). The peak heights were automatically analyzed using Genescan analysis software 3.7 (Applied Biosystems).

\subsection{Cloning and sequencing}

Clone libraries of AOA and AOB were constructed from the NO treatment using the primer pairs Arch-amoAF/Arch-amoAR and amoA1F/amoA2R without FAM labeling. The DNA extracted from the four replicates was mixed and used as the template for PCR. PCR conditions and purification were the same as the T-RFLP analysis. The purified PCR products were ligated with pGEM-T Easy Vector (Promega, Madison, WI) and then transformed into cells of Escherichia coli JM109 (Takara Biotechnology, Dalian, China) according to the manufacturer's instructions. Approximately 130 positive clones were randomly selected and then sequenced using an ABI 3730 sequencer (Applied Biosystems).
Sequence similarity was calculated with the software DNAMAN version 6.0.3.48 (Lynnon Biosoft, USA). For the sequences displaying $>97 \%$ similarity to each other, only one representative sequence was used for phylogenetic tree construction. The GenBank sequences most similar to clone sequences in the study and reference sequences with determined taxonomy were included in the phylogenetic tree construction. Phylogenetic analysis was performed using MEGA version 4.0 (Tamura et al., 2007), and the neighbor-joining tree was constructed by performing 1000 replicates to produce bootstrap values.

The sequences recorded in this study were deposited in the GenBank database (http://www.ncbi.nlm.nih.gov/genbank) with accession numbers KC311293 to KC311318 affiliated to AOA and KC311319 to KC311336 affiliated to AOB.

\subsection{Statistical analyses}

The amoA gene copies were log-transformed to provide variance homogeneity. Statistical analyses were performed based on SPSS version 16.0 (SPSS Inc., Chicago, IL, USA). Two-way ANOVAs were performed to examine the significance of treatment effects and their interactions on observed parameters. Duncan's protected least significant difference test was applied to examine quantitative differences between treatments.

\section{Results}

\subsection{Soil chemical properties}

As expected, the simulated precipitation increment resulted in higher soil water contents compared with the corresponding control treatments $(P<0.001$, Table 1$)$. Soil $\mathrm{pH}$ decreased with increasing $\mathrm{N}$ addition $(P<0.001)$, while the precipitation increment led to a significant increase in soil $\mathrm{pH}$ irrespective of $\mathrm{N}$ addition $(P<0.001)$.

Neither $\mathrm{N}$ addition nor precipitation increment showed significant effects on soil total $\mathrm{C}$ or $\mathrm{N}$ contents (Table 1 ). There were significant interactions between $\mathrm{N}$ addition and precipitation increment on soil $\mathrm{NH}_{4}{ }^{+}(P<0.001)$ and $\mathrm{NO}_{3}{ }^{-}(P<0.05)$ concentrations. Soil $\mathrm{NH}_{4}{ }^{+}$and $\mathrm{NO}_{3}{ }^{-}$concentrations under the $\mathrm{N} 15$ treatment were significantly higher than those under the NO and N5 treatments, irrespective of precipitation treatment, while the precipitation increment caused a significant decrease in soil $\mathrm{NH}_{4}{ }^{+}$and $\mathrm{NO}_{3}{ }^{-}$ concentrations only under the N15 treatment (Table 1 ).

\subsection{Potential nitrification rates (PNR)}

The PNR provides an indirect estimate of the abundance and activity of soil ammonia oxidizers. The highest PNR was recorded in the N15 treatment, and was 3.1 times higher than that in the NO treatment, while the lowest PNR was detected in the PNO treatment (Fig. 1). Generally, PNR increased with increasing $\mathrm{N}$ addition $(P<0.001)$, but decreased with the precipitation increment $(P<0.01)$. Significant interactions $(P<0.05)$ between precipitation increment and $\mathrm{N}$ addition on PNR were observed, as a significant decrease in PNR caused by precipitation increment was only detected under the N5, but not the N0 and N15 treatments.

In addition, PNR showed a positive correlation with soil $\mathrm{NH}_{4}{ }^{+}-$ $\mathrm{N}$ concentration $(r=0.635, P<0.001)$ and $\mathrm{NO}_{3}{ }^{-}-\mathrm{N}$ concentration $(r=0.602, P<0.01)$, but a negative correlation with soil water content $(r=-0.430, P<0.05)$ and soil $\mathrm{pH}(r=-0.817, P<0.001)$.

\subsection{Abundance of $A O A$ and $A O B$}

The abundance of AOA and AOB was estimated by quantifying the $a m o A$ gene. Significant differences were observed in the 
Table 1

Soil chemo-physical properties in a typical temperate steppe in Inner Mongolia as influenced by long-term nitrogen fertilization and simulated precipitation increment.

\begin{tabular}{|c|c|c|c|c|c|c|}
\hline Treatments & Water content (\%) & $\mathrm{pH}\left(\mathrm{H}_{2} \mathrm{O}\right)$ & Total C $\left(\mathrm{g} \mathrm{kg}^{-1}\right)$ & Total N $\left(\mathrm{g} \mathrm{kg}^{-1}\right)$ & $\mathrm{NH}_{4}{ }^{+}-\mathrm{N}\left(\mathrm{mg} \mathrm{kg}^{-1}\right)$ & $\mathrm{NO}_{3}{ }^{-}-\mathrm{N}\left(\mathrm{mg} \mathrm{kg}^{-1}\right)$ \\
\hline NO & $9.17 \mathrm{c}$ & $7.21 \mathrm{~b}$ & $16.72 \mathrm{a}$ & $1.51 \mathrm{a}$ & $10.16 c$ & $3.43 b$ \\
\hline N5 & $9.45 c$ & $6.93 c$ & $16.48 \mathrm{a}$ & $1.51 \mathrm{a}$ & $10.65 c$ & $9.83 b$ \\
\hline N15 & $8.58 \mathrm{c}$ & $6.13 e$ & $15.81 \mathrm{a}$ & $1.47 \mathrm{a}$ & $19.41 \mathrm{a}$ & $29.78 a$ \\
\hline PNO & $12.97 \mathrm{a}$ & $7.58 \mathrm{a}$ & $17.16 a$ & $1.53 \mathrm{a}$ & $9.56 c$ & $1.16 b$ \\
\hline PN5 & $12.14 \mathrm{ab}$ & $7.12 b$ & $15.98 a$ & $1.42 \mathrm{a}$ & $9.26 c$ & $2.14 b$ \\
\hline PN15 & $11.51 \mathrm{~b}$ & $6.74 d$ & $14.88 \mathrm{a}$ & $1.43 a$ & $12.41 b$ & $6.43 b$ \\
\hline \multicolumn{7}{|c|}{ Significance of } \\
\hline $\mathrm{N}$ & 0.034 & 0.000 & 0.307 & 0.704 & 0.000 & 0.001 \\
\hline $\mathrm{P}$ & 0.000 & 0.000 & 0.692 & 0.636 & 0.000 & 0.001 \\
\hline $\mathrm{N} \times \mathrm{P}$ & 0.311 & 0.002 & 0.787 & 0.828 & 0.000 & 0.025 \\
\hline
\end{tabular}

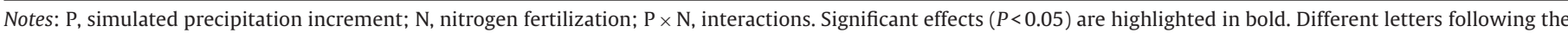
means $(n=4)$ in the same column indicate significant differences $(P<0.05)$ between corresponding treatments.

AOB amoA gene copy numbers among all treatments (Fig. 2a). The highest AOB amoA gene copy number was found in the PN15 treatment, which was 9.8 times higher than that in the N0 treatment. Both $\mathrm{N}$ addition and precipitation increment significantly increased AOB abundance $(P<0.001$ and $P<0.05$, respectively). In contrast to $A O B$, no significant difference in AOA amoA gene copy numbers was observed in any treatment (Fig. 2b). AOA amoA gene copies in all treatments, ranging from $1.03 \times 10^{10}$ to $9.00 \times 10^{9} \mathrm{~g}^{-1}$ dry soil, were generally higher than those of AOB amoA gene copies, ranging from $1.57 \times 10^{7}$ to $1.54 \times 10^{8} \mathrm{~g}^{-1}$ dry soil, and the ratios of AOA to AOB amoA gene copy numbers varied from 938 to 52 among all treatments. A positive correlation was observed between PNR and AOB amoA gene copies $(r=0.687, P<0.001$, Fig. $3 b)$, but there was a negative correlation with AOA amoA gene copies $(r=-0.415, P<0.05$, Fig. 3a). In addition, a negative correlation was found between AOB amoA copy numbers and soil pH $(r=-0.612$, $P<0.001)$.

\subsection{Community structure of $A O A$ and $A O B$}

Five terminal restriction fragments (TRFs) of AOB were detected from all soil samples by using the enzyme FastDigest ${ }^{\circledR}$ Mbo I (Fig. 4a), and significant variations in TRF abundance were observed among all treatments. The two-way ANOVA results showed that the overall effects of $\mathrm{N}$ addition and precipitation increment on $\mathrm{AOB}$ community composition were both significant

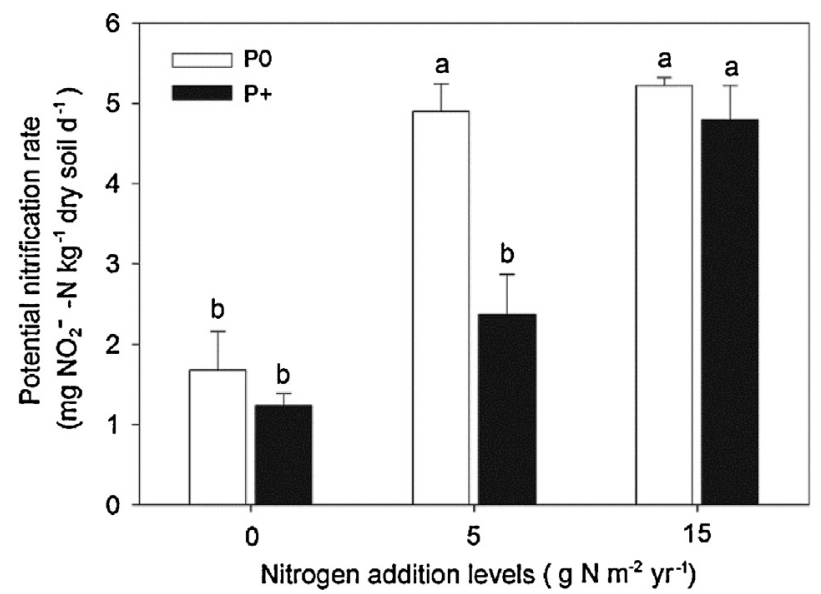

Fig. 1. Potential nitrification rate (PNR) in a typical temperate steppe in Inner Mongolia as influenced by $\mathrm{N}$ fertilization and simulated precipitation increment. $\mathrm{P} 0$ and $\mathrm{P}+$ refer to control and precipitation increment respectively. Columns stand for means of four replicates and bars indicate standard deviations. By ANOVA, effects of $\mathrm{N}$ fertilization and precipitation increment were both highly significant $(P<0.01)$, and their interactions were significant $(P<0.05)$. Different letters above the columns indicate significant differences $(\mathrm{a}=0.05$ ) between treatments according to Duncan's protected least significant difference test.
(Wilks Lambda $<0.01$ ). Moreover, $\mathrm{N}$ addition and precipitation increment interactively affected AOB community structure (Wilks Lambda $<0.01$ ). TRFs of $109 \mathrm{bp}$ and $280 \mathrm{bp}$ were the dominant groups in all treatments. The relative abundance of $109 \mathrm{bp}$ was highest in the N15 treatment and lowest in the PN0 treatment (Fig. 4a), whereas the relative abundance of 280 bp showed an opposite trend. Nitrogen addition significantly affected the relative abundance of all AOB TRFs (Table 2). The effect of increased precipitation on the relative abundance of AOB TRFs was also significant for $109 \mathrm{bp}, 169 \mathrm{bp}$ and $280 \mathrm{bp}$.

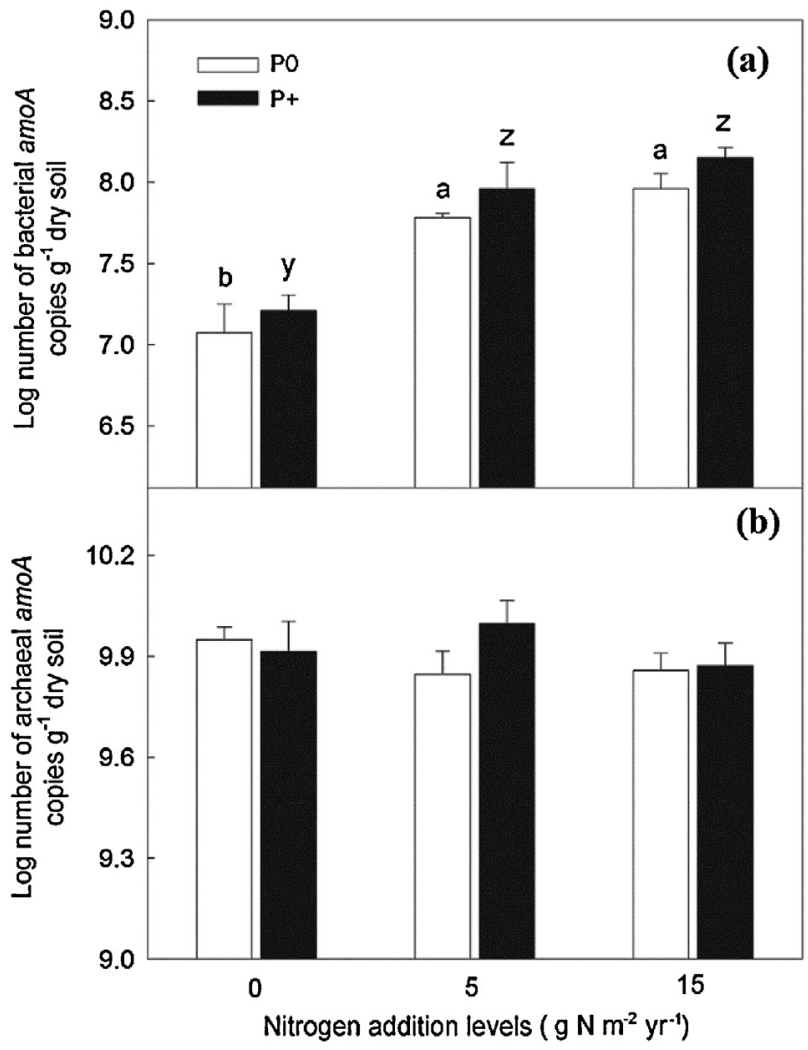

Fig. 2. Abundance of bacterial (a) and archaeal (b) amoA gene copy numbers in a typical temperate steppe in Inner Mongolia as influenced by $\mathrm{N}$ fertilization and simulated precipitation increment. $\mathrm{P} 0$ and $\mathrm{P}+$ refer to control and precipitation increment respectively. Columns stand for means of four replicates and bars indicate standard deviations. For bacterial amoA gene copy numbers, effects of $\mathrm{N}$ fertilization were highly significant $(P<0.01)$, while effects of precipitation increment were significant $(P<0.05)$. No significant interactions were observed. Different letters above the columns indicate significant differences $(a=0.05)$ between different $\mathrm{N}$ addition levels under the same precipitation treatment according to Duncan's protected least significant difference test. For archaeal (b) amoA gene copy numbers, neither $\mathrm{N}$ fertilization nor precipitation showed significant effects, nor did their interactions. 


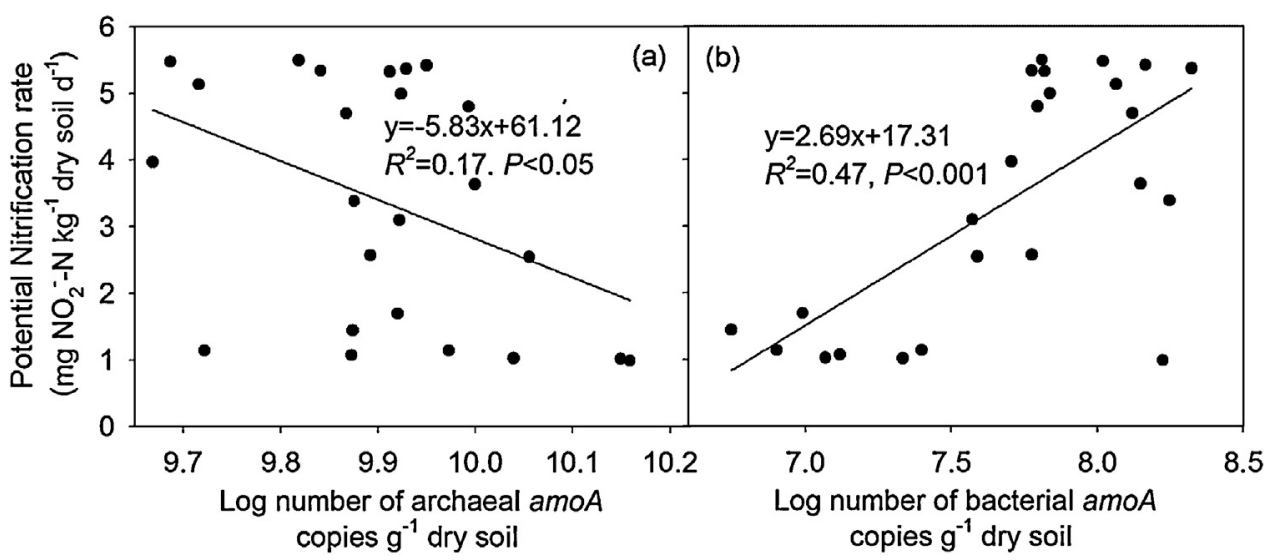

Fig. 3. Relationship between potential nitrification rate (PNR) and log number of archaeal (a) and bacterial (b) amoA copies.

In contrast, eight AOA TRFs were observed using the enzymes FastDigest ${ }^{\circledR}$ Mbo I, and AOA were less variable than AOB (Fig. 4b). The two-way ANOVA showed that neither $\mathrm{N}$ addition nor precipitation increment had significant effects on AOA community composition (Wilks Lambda >0.05). $73 \mathrm{bp}, 329 \mathrm{bp}, 421 \mathrm{bp}$ and $443 \mathrm{bp}$ were the dominant TRFs, with their relative abundances ranging from 7.0 to $48.4 \%$ (Fig. $4 \mathrm{~b}$ ). The effect of precipitation increment on the relative abundance of AOA TRFs was significant for the $58 \mathrm{bp}, 329 \mathrm{bp}$ and $421 \mathrm{bp}$, whereas the effect of $\mathrm{N}$ addition was only significant for $329 \mathrm{bp}$ and $421 \mathrm{bp}$. Significant interactions
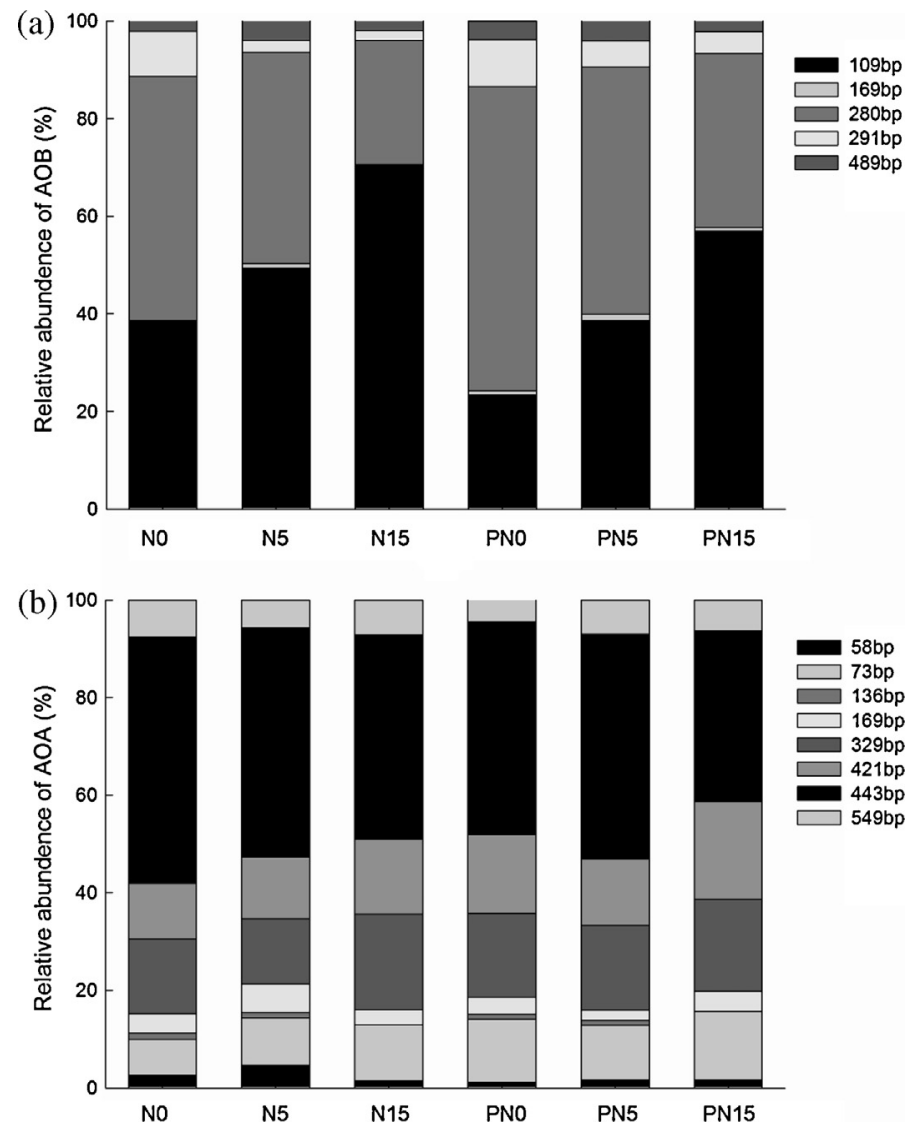

Fig. 4. Relative abundance of T-RFs of bacterial (a) and archaeal (b) amoA gene restricted by $M b o$ I in a typical temperate steppe in Inner Mongolia as influenced by $\mathrm{N}$ fertilization and simulated precipitation increment. $\mathrm{P}$ refers to precipitation increment, while N0, N5 and N15 refer to $\mathrm{N}$ addition level of 0,5 and $15 \mathrm{~g} \mathrm{~N} \mathrm{~m}^{-2} \mathrm{yr}^{-1}$ respectively. between $\mathrm{N}$ addition and precipitation increment were observed on the relative abundance of $329 \mathrm{bp}$ (Table 3 ), as precipitation increment significantly increased 329 bp abundance under the NO and N5 treatment, but was the opposite under the N15 treatment.

\subsection{Phylogeny of $A O A$ and $A O B$}

A total of 111 archaeal and 113 bacterial amoA gene sequences from the NO treatment, which contained all the AOA and AOB TRFs types, were included for the phylogenetic analysis. The results indicated that all AOB clones were affiliated within Nitrosospira cluster 3a.1, cluster 3a.2, cluster 3b, cluster 9 and cluster 11/12 (Fig. 5). Only the TRFs of $109 \mathrm{bp}$ and $280 \mathrm{bp}$ were detected in AOB sequences. The clones of 280 bp TRFs were assigned to clusters 3a.1, 3a.2 and 9, while those of $109 \mathrm{bp}$ TRFs were assigned to all five clusters. In addition, the AOB community was dominated by cluster 3a.1 (59.3\%) and clusters 3a.2 (27.4\%).

Cloning and sequencing of AOA amoA genes showed that all sequences were affiliated to the soil and sediment lineage, and were designated as soil and sediment clusters 1, 2 and 3 (Fig. 6). All the AOA TRFs except $58 \mathrm{bp}$ in T-RFLP profiles were detected in AOA clones. The $136 \mathrm{bp}$ and $443 \mathrm{bp}$ TRFs only emerged in soil and sediment 2 , whereas the TRF of 169 bp only existed in soil and sediment 3 and $549 \mathrm{bp}$ in soil and sediment 1 . The $73 \mathrm{bp}$ and $329 \mathrm{bp}$ TRFs were found in soil and sediment 1 and 2, while 421 bp TRF was found in soil and sediment 1 and 3 . A few remaining sequences ( 4 of 111 clones) whose restriction sites were not found in analysis were affiliated in soil and sediment 2 .

\section{Discussion}

\subsection{Effects of nitrogen fertilization and increased precipitation on abundance of $A O A$ and $A O B$}

In this study, AOA greatly outnumbered AOB, which is consistent with previous findings in different ecosystems (Könneke et al., 2005; Leininger et al., 2006; He et al., 2007; Shen et al., 2008). In the

Table 2

Two-way ANOVA of the relative abundance of AOB TRFs digested with restricted enzyme Mbo I.

\begin{tabular}{llllll}
\hline & $109 \mathrm{bp}$ & $169 \mathrm{bp}$ & $280 \mathrm{bp}$ & $291 \mathrm{bp}$ & $489 \mathrm{bp}$ \\
\hline $\mathrm{P}$ & $\mathbf{0 . 0 0 2}$ & $\mathbf{0 . 0 4 6}$ & $\mathbf{0 . 0 0 1}$ & 0.243 & 0.188 \\
$\mathrm{~N}$ & $\mathbf{0 . 0 0 0}$ & $\mathbf{0 . 0 1 0}$ & $\mathbf{0 . 0 0 0}$ & $\mathbf{0 . 0 0 7}$ & $\mathbf{0 . 0 2 1}$ \\
$\mathrm{P} \times \mathrm{N}$ & 0.853 & 0.931 & 0.843 & 0.689 & 0.341 \\
\hline
\end{tabular}

Notes: $\mathrm{P}$, simulated precipitation increment; $\mathrm{N}$, nitrogen fertilization; $\mathrm{P} \times \mathrm{N}$, interactions. Significant effects $(P<0.05)$ are highlighted in bold. 
Table 3

Two-way ANOVA of the relative abundance of AOA TRFs digested with restricted enzyme Mbo I.

\begin{tabular}{|c|c|c|c|c|c|c|c|c|}
\hline & 58 bp & 73 bp & 136 bp & $169 \mathrm{bp}$ & 329 bp & $421 \mathrm{bp}$ & 443 bp & 549 bp \\
\hline $\mathrm{P}$ & 0.028 & 0.152 & 0.808 & 0.187 & 0.045 & 0.001 & 0.318 & 0.650 \\
\hline $\mathrm{N}$ & 0.108 & 0.596 & 0.709 & 0.994 & 0.015 & 0.002 & 0.093 & 0.865 \\
\hline $\mathrm{P} \times \mathrm{N}$ & 0.120 & 0.801 & 0.573 & 0.057 & 0.048 & 0.564 & 0.248 & 0.353 \\
\hline
\end{tabular}

Notes: $\mathrm{P}$, simulated precipitation increment; $\mathrm{N}$, nitrogen fertilization; $\mathrm{P} \times \mathrm{N}$, interactions. Significant effects $(P<0.05)$ are highlighted in bold.

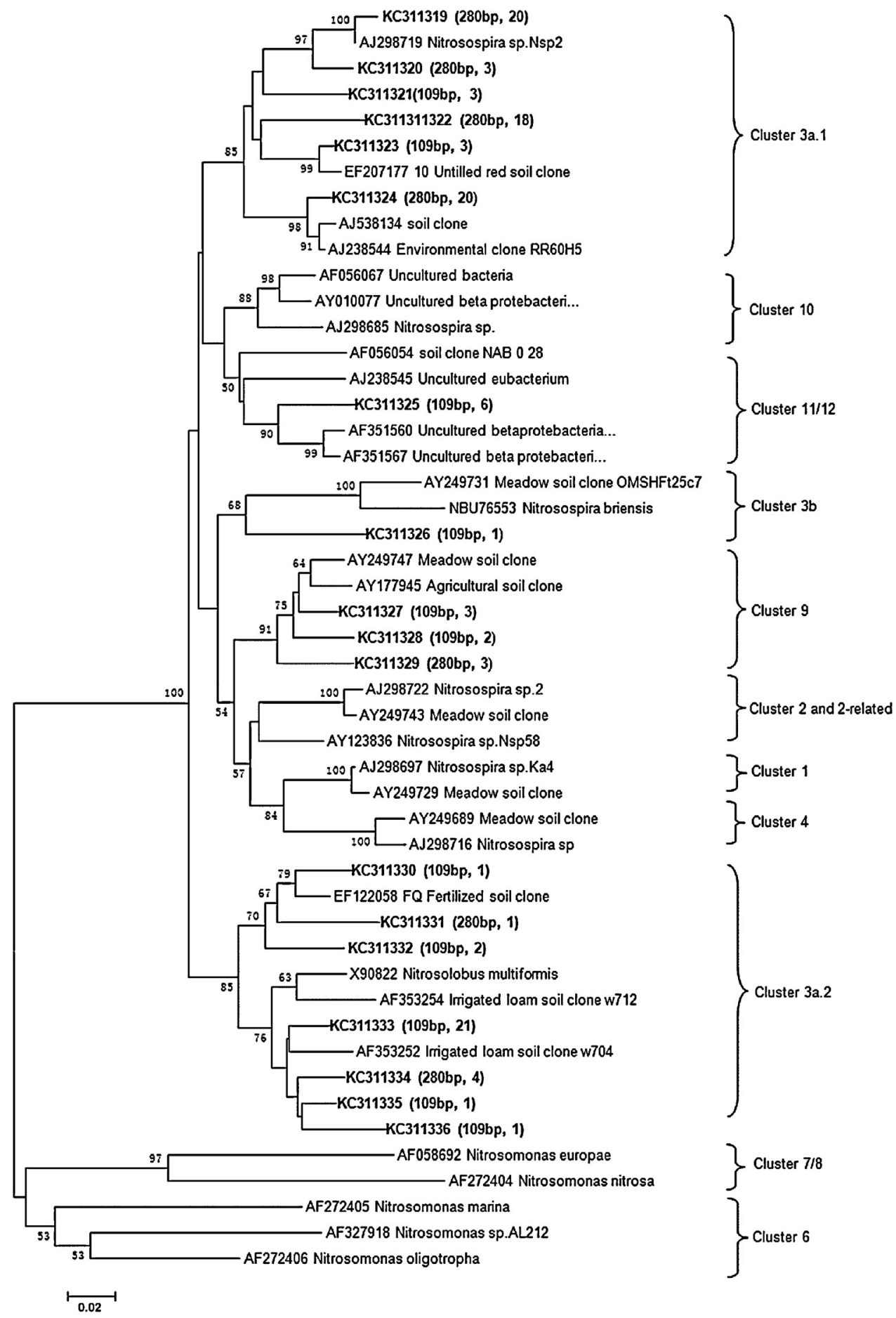

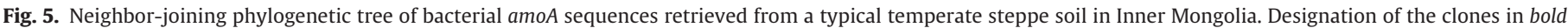

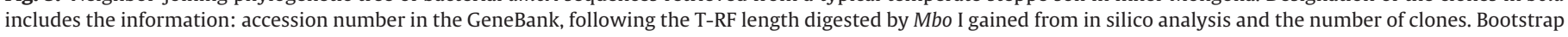
values ( $>50)$ are indicated at branch points. The scale bar represents $2 \%$ estimated sequence divergence. 


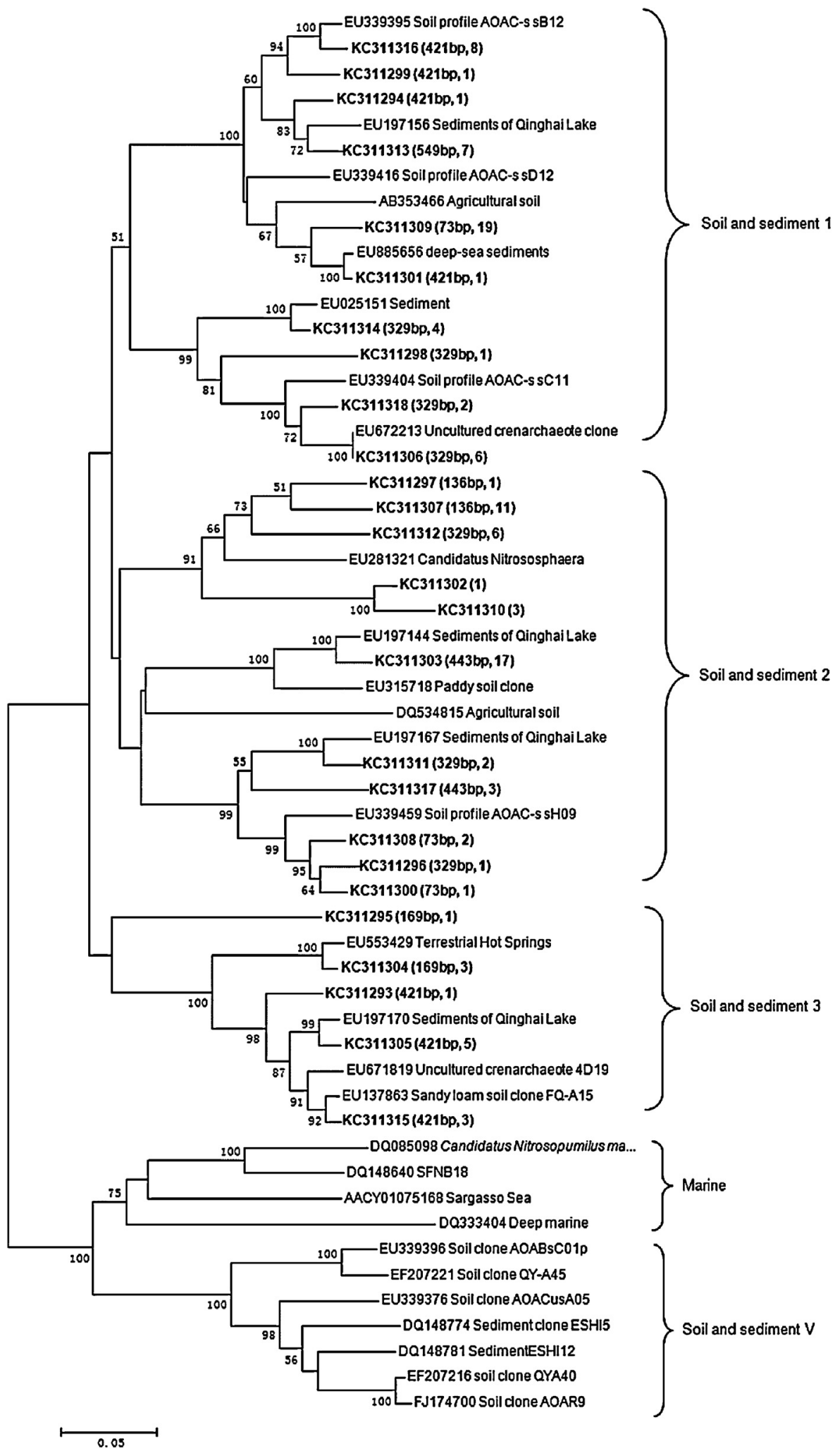

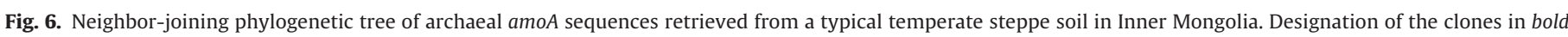

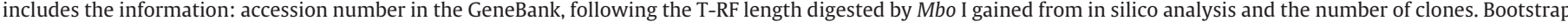
values $(>50)$ are indicated at branch points. The scale bar represents $5 \%$ estimated sequence divergence.

soils tested here, long-term $\mathrm{N}$ addition significantly increased AOB abundance while no significant differences in AOA abundance were found among treatments, indicating that $\mathrm{N}$ was an important driving factor for abundance of AOB but not AOA. Similarly, Shen et al. (2008) found a significant increase in AOB amoA gene copies but not
AOA following 17 years of $\mathrm{N}$ fertilization in an alkaline sandy soil. In a series of soil microcosms, AOB abundance responded positively to the addition of $\mathrm{N}$ fertilizers, whereas the AOA abundance remained stable or was even decreased by high levels of $\mathrm{N}$ amendment (Di et al., 2009, 2010; Verhamme et al., 2011). Di et al. (2010) also found 
that the growth of AOB was favored by high ammonia substrate, while that of AOA was favored by low ammonia substrate. All these studies showed that $A O A$ can out-compete $A O B$ under conditions of low fertility, whereas AOB seems to gain a competitive advantage in fertilized soils.

The ammonia substrate availability is thought to be a dominant factor determining the growth and ecological niches of AOA and $\mathrm{AOB}$, as the ammonia oxidation process provides the energy source for the ammonia oxidizers. However, recent studies have shown that thaumarchaea can use organic C other than ammonia, suggesting a mixotrophic or heterotrophic lifestyle. Nitrososphaera viennensis, a soil-isolated archaeon, can grow mixotrophically on urea or ammonia with addition of pyruvate (Tourna et al., 2011). In a microcosm study, thaumarchaeal growth was also observed when ammonia oxidization was completely inhibited by acetylene (Jia and Conrad, 2009). Furthermore, AOA showed a higher affinity for substrate than AOB did (Martens-Habbena et al., 2009; Martens-Habbena and Stahl, 2011). For example, N. maritimus, a marine-isolated AOA strain, showed the lowest half-saturation constant $\left(K_{\mathrm{m}}=0.13 \mu \mathrm{m}\right)$ among all the cultured ammonia oxidizers, with an affinity for ammonia 200-fold higher than that of AOB. Taken together, the specific physiological characteristics of AOA allow them to survive at potential niches (low ammonia concentrations) that are unsuitable to the $\mathrm{AOB}$, as a result they show different responses to $\mathrm{N}$ fertilizers.

The ammonia oxidation induced by long-term $\mathrm{N}$ addition can lead to net proton accumulation in the soil, which subsequently contributes to lower soil $\mathrm{pH}$ (Pernes-Debuyser and Tessier, 2004). In the present study, a significant decrease in soil $\mathrm{pH}$ was observed in all experimental plots supplied with $\mathrm{N}$ fertilizer in comparison with the NO treatment (Table 1 ), and soil pH showed a significantly negative correlation with the abundance of AOB $(r=-0.612, P<0.01)$. However, no significant correlation was observed between soil $\mathrm{pH}$ and AOA abundance, which was consistent with the findings of Shen et al. (2008) in an alkaline soil. Obviously, soil pH may have played an important role in influencing AOB but not AOA populations in this steppe. In other words, the observed shifts in AOB abundance with long-term $\mathrm{N}$ fertilization could be partially attributed to changes in soil $\mathrm{pH}$.

Increased precipitation significantly increased the abundance of $A O B$ but not $A O A$, indicating that water was another important factor influencing AOB, while AOA had a strong tolerance to soil moisture variations. Singh and Kashyap (2006) showed that the population size of AOB was higher in the rainy season than that in the dry summer season. Similarly, Gleeson et al. (2010) reported that the highest AOB abundance was observed at 65\% WFPS, while AOA abundance remained stable in a series of moisture gradients. In another microcosm study, increasing water holding capacity resulted in significantly higher AOB abundance and PNR (Avrahami and Bohannan, 2007). However, AOA were more abundant at $40 \%$ than 70\% WFPS, suggesting that reduced oxygen levels inhibited AOA growth in a Rothwald acidic soil (Szukics et al., 2012). Liu et al. (2009) showed that water was an important limiting factor in regulating soil microbial respiration and microbial biomass. Ammonia oxidizers may be highly sensitive to water stresses, which can affect their activity through dehydration and substrate limitation (Stark and Firestone, 1995).

Microorganisms have evolved different strategies to adapt to moisture stresses, depending on their evolutionary adaptations and physiological acclimation mechanisms (Schimel et al., 2007). The different responses of $A O A$ and $A O B$ to soil moisture can also be explained from their different biochemical and genetic features. It has been suggested that $\mathrm{AOB}$, as Gram-negative bacteria with a single-layer cell wall and an outer membrane, are more sensitive to changes in soil moisture than other soil microorganisms (Schimel et al., 2007). Compared with bacterial membranes, archaeal membranes are less permeable (Valentine, 2007), thus a stable growth and an undisturbed physiological process can be ensured. Given that only AOB abundance changed with $\mathrm{N}$ addition and increased precipitation, we conclude that $A O B$ were more sensitive than AOA for forecasting the effect of climate change on terrestrial ecosystems.

\subsection{Effects of nitrogen fertilization and precipitation increment on community structure of $A O A$ and $A O B$}

T-RFLP analysis showed that AOB community structure significantly varied among different treatments. However, the AOA T-RFLP remained relatively stable in response to $\mathrm{N}$ addition, suggesting that $\mathrm{N}$ is a key factor influencing $\mathrm{AOB}$ but not AOA composition in this study area. There was a significant negative correlation between the $H$ values (data not shown) of AOB and AOB amoA gene abundance $(r=-0.440, P<0.05)$, indicating that the change of AOB abundance was likely due to shifts in AOB community composition. Similar results were obtained in a series of previous studies (Shen et al., 2008, 2011; Ke and Lu, 2012). In an alkaline soil, Shen et al. (2008) reported that long-term N fertilization practices significantly changed AOB community structure, with marginal effects on AOA community structure. In microcosm studies, clear effects of $\mathrm{N}$ on the $\mathrm{AOB}$ community were also observed, whereas the AOA community remained unchanged (Ke and $\mathrm{Lu}, 2012$ ).

Changes in AOA community composition in response to longterm fertilization have also been found in acid soils (He et al., 2007; Ying et al., 2010; Chen et al., 2011). He et al. (2007) found a pronounced difference in the community composition of AOA responding to the long-term fertilization practices in a Chinese upland red soil. In another acid paddy soil, changes in AOA community composition in response to long-term fertilization practices were found by Chen et al. (2011). Probably AOA is more sensitive than $A O B$ in responding to fertilization in acidic soils, whereas AOB is more sensitive to fertilization than AOA in alkaline soils. Thus, soil type is most likely a key factor in determining the community composition of ammonia oxidizers.

In the present study, $\mathrm{AOB}$ composition was significantly affected by the increased precipitation (Wilks Lambda $=0.002$ ), while AOA communities were only marginally influenced, suggesting that water was another key factor influencing AOB community structure. For example, the relative abundance of AOB $109 \mathrm{bp}$ TRF under precipitation increment was significantly lower $(P=0.002)$ than that under control treatments, whereas the relative abundance of AOB 280 bp TRF showed an opposite trend $(P=0.001)$. However, both AOA and AOB community structures were highly responsive to soil water availability in a previous study (Gleeson et al., 2010). There seemed to be two different clusters of AOB and AOA communities in the soil, one adapted to oxic conditions while the other adapted to sub-oxic environments. In a Rothwald acidic soil, AOA community composition appeared to be sensitive to changes in soil water content (Szukics et al., 2012). Angel et al. (2010) studied the diversity of soil archaea and bacteria along a steep precipitation gradient ranging from an arid Negev Desert to a Mediterranean forest, and water content was observed to correlate significantly with the community profiles of both domains. The reason for the inconsistency in different studies is probably the different soil types and soil moisture.

The present study showed that $\mathrm{N}$ fertilizer and increased precipitation interactively affect AOB community structure (Wilks Lambda $<0.01$ ), suggesting that the AOB community responses to $\mathrm{N}$ deposition can be mediated by precipitation regimes. The results provided field evidence for the interactive effects of $\mathrm{N}$ addition and increased precipitation on the AOB community for the first time. A number of studies have shown that $\mathrm{N}$ and water co-limited 
grassland productivity (Hooper and Johnson, 1999; Harpole et al., 2007). However, responses of the microbial community to the changes in precipitation regimes and $\mathrm{N}$ deposition were still unclear. When examining the effects of $\mathrm{N}$ deposition on ecosystems, there is a need to take into account potential changes in precipitation regimes and vice versa.

All AOA clones identified in this study were affiliated within the soil and sediment lineage (Cluster S), and none was affiliated with the marine lineage (Cluster M), suggesting that AOA sequences in the test soils have a dissimilar origin with marine sequences. Similarly, Shen et al. (2011) also found that all AOA clones were classified into the soil and sediment lineage in a semiarid grassland. However, some other studies showed that Cluster S and Cluster M coexisted, while Cluster S dominated AOA in agricultural and grassland soils (He et al., 2007; Shen et al., 2008; Di et al., 2009). Phylogenetic analysis of AOB identified only Nitrosospira species but no Nitrosomonas species in this study, which was consistent with previous studies (Webster et al., 2002; Chu et al., 2007; Di et al., 2009). In addition, Nitrosospira Cluster 3 (including the subclusters 3a.1, 3a.2 and 3b) was found to be the dominant AOB cluster, which is in agreement with previous studies that Nitrosospira Cluster 3 was most common in a number of arable soils (He et al., 2007; Shen et al., 2008) and grassland soils (Di et al., 2009; Shen et al., 2011). The results suggested that high $\mathrm{N}$ deposition in the typical steppe may have resulted in preferable growth of AOB Cluster 3.

\subsection{Relative contribution of $A O A$ and $A O B$ to nitrification}

The relative contribution of $\mathrm{AOA}$ and $\mathrm{AOB}$ to nitrification has been controversial since Leininger et al. (2006) first reported the dominance of AOA over AOB in 12 European soils. Regression analysis showed a significant positive correlation between PNR and AOB abundance, while a significant negative correlation was observed with AOA, suggesting that AOB may play a key role in nitrification processes in the temperate steppe that we have studied. Such results strongly support previous studies that nitrification was mainly driven by AOB in some grassland and agricultural soils (Di et al., 2009; Jia and Conrad, 2009; Xia et al., 2011). Several other studies have suggested that AOA are mainly responsible for the nitrification in acidic soils (Gubry-Rangin et al., 2010; Yao et al., 2011; Zhang et al., 2012). However, recently Zhang et al. (2010) confirmed that AOA also appear to influence nitrification in alkaline soils. Obviously, more systematic studies are still required to reveal the contribution of $A O A$ and $A O B$ to nitrification in various soils worldwide.

\section{Conclusion}

In conclusion, the present study provides convincing evidence for the effect of long-term $\mathrm{N}$ addition and increased precipitation on soil ammonia oxidizers in a typical temperate steppe. It was found that both long-term $\mathrm{N}$ addition and increased precipitation had significant impacts on PNR, abundance and community structure of $A O B$, but marginal effects on $A O A$, suggesting that $A O B$ were more sensitive than $A O A$ to $N$ addition and precipitation increment. Although AOA dominate over AOB in the ammonia oxidizer community, AOB may take more responsibility for nitrification in this research area. It remains uncertain whether the higher AOA amoA gene copies contribute to nitrification.

\section{Acknowledgments}

We would like to thank Dan Xiang and Wenping Zhou for assistance with soil sampling. The study was financially supported by
Knowledge Innovation Program of the Chinese Academy of Sciences (KZCX2-YW-BR-17), State Key Laboratory of Urban and Regional Ecology (SKLURE2008-1-03), National Natural Science Foundation of China (31000200) and the National Basic Research Program of China (2011CB403204).

\section{References}

Angel, R., Soares, M.I., Ungar, E.D., Gillor, O., 2010. Biogeography of soil archaea and bacteria along a steep precipitation gradient. ISME J. 4, 553-563.

Avrahami, S., Bohannan, B.J.A., 2007. Response of Nitrosospira sp strain AF-like ammonia oxidizers to changes in temperature, soil moisture content, and fertilizer concentration. Appl. Environ. Microbiol. 73, 1166-1173.

Blainey, P.C., Mosier, A.C., Potanina, A., Francis, C.A., Quake, S.R., 2011. Genome of a low salinity ammonia-oxidizing archaeaon determined by single-cell and metagenomic analysis. PLoS ONE 6, 1-12.

Brochier-Armanet, C., Boussau, B., Gribaldo, S., Forterre, P., 2008. Mesophilic crenarchaeota: proposal for a third archaeal phylum, the Thaumarchaeota. Nat. Rev. Microbiol. 6, 245-252.

Chen, X., Zhang, L.M., Shen, J.P., Wei, W.X., He, J.Z., 2011. Abundance and community structure of ammonia-oxidizing archaea and bacteria in an acid paddy soil. Biol. Fertil. Soils 47, 323-331.

Chu, H.Y., Fujii, T., Morimoto, S., Lin, X.G., Yagi, K., Hu, J.L., Zhang, J.B., 2007. Community structure of ammonia oxidizing bacteria under long-term application of mineral fertilizer and organic manure in a sandy loam soil. Appl. Environ. Microbiol. 73, 485-491.

Di, H.J., Cameron, K.C., Shen, J.P., Winefield, C.S., Callaghan, M.O., Bowatte, S., He, J.Z., 2010. Ammonia-oxidizing bacteria and archaea grow under contrasting soil nitrogen conditions. FEMS Microbiol. Ecol. 72, 386-394.

Di, H.J., Cameron, K.C., Shen, J.P., Winefield, C.S., Callaghan, M.O., Bowatte, S., He, J.Z., 2009. Nitrification driven by bacteria and not archaea in nitrogen-rich grassland soils. Nat. Geosci. 2, 621-624.

Dore, M.H.I., 2005. Climate change and changes in global precipitation patterns: what do we know? Environ. Int. 31, 1167-1181.

Francis, C.A., Roberts, K.J., Beman, J.M., Santoro, A.E., Oakley, B.B., 2005. Ubiquity and diversity of ammonia-oxidizing archaea in water columns and sediments of the ocean. PNAS 102, 14683-14688.

Gleeson, D.B., Herrmann, A.M., Livesley, S.J., Murphy, D.V., 2008. Influence of water potential on nitrification and structure of nitrifying bacterial communities in semiarid soils. Appl. Soil Ecol. 40, 189-194.

Gleeson, D.B., Müller, C., Banerjee, S., Ma, W., Siciliano, S.D., Murphy, S.D., 2010. Response of ammonia oxidizing archea and bacteria to changing water filled pore space. Soil Biol. Biochem. 42, 1888-1891.

Gough, L., Osenberg, C.W., Gross, K.L., Collins, S.L., 2000. Fertilization effects on species density and primary productivity in herbaceous plant communities. Oikos 89, 428-439.

Gubry-Rangin, C., Nicol, G.W., Prosser, J.I., 2010. Archaea rather than bacteria control nitrification in two agricultural acidic soils. FEMS Microbiol. Ecol. 74, 566-574.

Guo, J.H., Liu, X.J., Zhang, Y., Shen, J.L., Han, W.X., Zhang, W.F., Christie, P., Goulding, K.W.T., Vitousek, P.M., Zhang, F.S., 2010. Significant acidification in major Chinese croplands. Science 327, 1008-1010.

Hallam, S.J., Mincer, T.J., Schleper, C., Preston, C.M., Roberts, K., Richardson, P.M. DeLong, E.F., 2006. Pathways of carbon assimilation and ammonia oxidation suggested by environmental genomic analyses of marine Crenarchaeota. PLoS Biol. 4, 0520-0536.

Harpole, W.S., Potts, D.L., Suding, K.N., 2007. Ecosystem responses to water and nitrogen amendment in a California grassland. Global Change Biol. 13 2341-2348.

He, J.Z., Hu, H.W., Zhang, L.M., 2012. Current insights into the autotrophic thaumarchaeal ammonia oxidation in acidic soils. Soil Biol. Biochem. 12 146-154.

He, J.Z., Shen, J.P., Zhang, L.M., Zhu, Y.G., Zheng, Y.M., Xu, M.G., 2007. Quantitative analyses of the abundance and composition of ammonia-oxidizing bacteria and ammonia-oxidizing archaea of a Chinese upland red soil under long-term fertilization practices. Environ. Microbiol. 9, 2364-2374.

Hooper, D.U., Johnson, L., 1999. Nitrogen limitation in dryland ecosystems: responses to geographical and temporal variation in precipitation. Biogeochemistry $46,247-293$.

IPCC, 2007. Climate change 2007: the physical science basis: summary for policymakers. IPCC WGI Fourth Assessment Report.

Jia, Z.J., Conrad, R., 2009. Bacteria rather than Archaea dominate microbial ammonia oxidation in an agricultural soil. Environ. Microbiol. 11, 1658-1671.

Ke, X.B., Lu, Y.H., 2012. Adaptation of ammonia-oxidizing microbes to environment shift of paddy field soil. FEMS Microbiol. Ecol. 80, 87-97.

Könneke, M., Bernhard, A.E., de la Torre, J.R., Walker, C.B., Waterbury, J.B., Stahl, D.A., 2005. Isolation of an autotrophic ammonia-oxidizing marine archaeon. Nature 437, 543-546.

Kurola, J., Salkinoja-Salonen, M., Aarnio, T., Hultman, J., Romantschuk, M., 2005 Activity, diversity and population size of ammonia-oxidising bacteria in oilcontaminated land farming soil. FEMS Microbiol. Lett. 250, 33-38.

Leininger, S., Urich, T., Schloter, M., Schwark, L., Qi, J., Nicol, G.W., 2006. Archaea predominate among ammonia-oxidizing prokaryotes in soils. Nature 442, 806-809. 
Liu, W.X., Zhang, Z., Wan, S.Q., 2009. Predominant role of water in regulating soil and microbial respiration and their responses to climate change in a semiarid grassland. Global Change Biol. 15, 184-195.

Martens-Habbena, W., Berube, P.M., Urakawa, H., de la Torre, J.R., Stahl, D.A., 2009. Ammonia oxidation kinetics determines niche separation of nitrifying Archaea and Bacteria. Nature 461, 976-979.

Martens-Habbena, W., Stahl, D.A., 2011. Nitrogen metabolism and kinetics of ammonia-oxidizing archaea. Methods Enzymol. 496, 465-487.

Ni, J., Zhang, X.S., 2000. Climate variability, ecological gradient and the Northeast China Transect (NECT). J. Arid Environ. 46, 313-325.

Nicol, G.W., Leininger, S., Schleper, C., Prosser, J.I., 2008. The influence of soil pH on the diversity, abundance and transcriptional activity of ammonia oxidizing archaea and bacteria. Environ. Microbiol. 10, 2966-2978.

Niu, S.L., Wu, M.Y., Han, Y., Xia, J.Y., Li, L.H., Wan, S.Q., 2008. Water mediated responses of ecosystem carbon fluxes to climatic change in a temperate steppe. New Phytol. 77, 209-219.

Norton, J.M., Stark, J.M., 2011. Regulation and measurement of nitrification in terrestrial systems. Methods Enzymol. 486, 343-368.

Offre, P., Prosser, J.I., Nicol, G.W., 2009. Growth of ammonia-oxidizing archaea in soil microcosms is inhibited by acetylene. FEMS Microbiol. Ecol. 70, 99-108.

Pernes-Debuyser, A., Tessier, D., 2004. Soil physical properties affected by long-term fertilization. Eur. J. Soil Sci. 55, 505-512.

Rotthauwe, J.H., Witzel, K.P., Liesack, W., 1997. The ammonia monooxygenase structural gene amoA as a functional marker: molecular fine-scale analysis of natural ammonia-oxidizing populations. Appl. Environ. Microbiol. 63, 4704-4712.

Schimel, J., Balser, T.C., Wallenstein, M., 2007. Microbial stress response physiology and its implications for ecosystem function. Ecology 88, 1386-1394.

Shen, J.P., Zhang, L.M., Zhu, Y.G., Zhang, J.B., He, J.Z., 2008. Abundance and composition of ammonia-oxidizing bacteria and ammonia-oxidizing archaea communities of alkaline sandy loam. Environ. Microbiol. 10, 1601-1611.

Shen, X.Y., Zhang, L.M., Shen, J.P., Li, L.H., Yuan, C.L., He, J.Z., 2011. Nitrogen loading levels affect abundance and composition of soil ammonia oxidizing prokaryotes in semiarid temperate grassland. J. Soils Sediments 11, 1243-1252.

Singh, J.S., Kashyap, A.K., 2006. Dynamics of viable nitrifier community, Nmineralization and nitrification in seasonally dry tropical forests and savanna. Microbiol. Res. 161, 169-179.

Stark, J.M., Firestone, M.K., 1995. Mechanisms for soil moisture effects on activity of nitrifying bacteria. Appl. Environ. Microbiol. 61, 218-221.

Stevens, C.J., Dise, N.B., Mountford, J.O., Gowing, D.J., 2004. Impact of nitrogen deposition on the species richness of grasslands. Science 303, 1876-1879.

Szukics, U., Abell, G.C.J., Hodl, V., Mitter, B., Sessitsch, A., Hackl, E., Boltenstern, S.Z., 2010. Nitrifiers and denitrifiers respond rapidly to changed moisture and increasing temperature in a pristine forest soil. FEMS Microbiol. Ecol. 72, 395-406.

Szukics, U., Hackla, E., Zechmeister-Boltenstern, S., Sessitsch, A., 2012. Rapid and dissimilar response of ammonia oxidizing archaea and bacteria to nitrogen and water amendment in two temperate forest soils. Microbiol. Res. 67, 103-109.

Tamura, K., Dudley, J., Nei, M., Kumar, S., 2007. MEGA4: Molecular Evolutionary Genetics Analysis (MEGA) software version 4.0. Mol. Biol. Evol. 24, 1596-1599.

Tourna, M., Stieglmeier, M., Spang, A., Könneke, M., Schintlmeister, A., Urich, T., Engel, M., Schloter, M., Wagner, M., Richter, A., Schleper, C., 2011. Nitrososphaera viennensis, an ammonia oxidizing archaeon from soil. PNAS 20, 8420-8425.
Treusch, A.H., Leininger, S., Kletzin, A., Schuster, S.C., Klenk, H.P., Schleper, C., 2005. Novel genes for nitrite reductase and Amo-related proteins indicate a role of uncultivated mesophilic crenarchaeota in nitrogen cycling. Environ. Microbiol. 7, 1985-1995.

Valentine, D.L., 2007. Adaptations to energy stress dictate the ecology and evolution of the archaea. Nat. Rev. Microbiol. 5, 316-323.

Venter, J.C., Remington, K., Heidelberg, J.F., Halpern, A., Rusch, D., Eisen, J., Wu, D. Paulsen, I., Nelseon, K., Nelson, W., Fouts, D., Levy, S., Knap, A., Lomas, M., Nealson, K., White, O., Peterson, J., Hoffman, J., Parsons, R., Tillson, H.B., Pfannkoch, C., Rogers, Y., Smith, H., 2004. Environmental genome shotgun sequencing of the Sargasso Sea. Science 304, 66-74.

Verhamme, D.T., Prosser, J.I., Nicol, G.W., 2011. Ammonia concentration determines differential growth of ammonia-oxidising archaea and bacteria in soil microcosms. ISME J. 5, 1067-1071.

Walker, C.B., de la Torre, J.R., Klotz, M.G., Urakawa, H., Pinela, N., Arp, D.J., BrochierArmanet, C., Chain, P.S., Chan, P.P., Gollabgir, A., Hemp, J., Hügler, M., Karr, E.A., Könneke, M., Shin, M., Lawton, T.J., Lowe, T., Martens-Habbena, W., SayavedraSoto, L.A., Lang, D., Sievert, S.M., Rosenzweig, A.C., Manning, G., Stahl, D.A., 2010. Nitrosopumilus maritimus genome reveals unique mechanisms for nitrification and autotrophy in globally distributed marine crenarchaea. PNAS 107, 8818-8823.

Webster, G., Embley, T.M., Prosser, J.I., 2002. Grassland management regimens reduce small-scale heterogeneity and species diversity of $\beta$-proteobacterial ammonia oxidizer populations. Appl. Environ. Microbiol. 68, 20-30.

Xia, J.Y., Wan, S.Q., 2008. Global response patterns of terrestrial plant species to nitrogen addition. New Phytol. 179, 428-439.

Xia, W.W., Zhang, C.X., Zeng, X.W., Feng, Y.Z., Weng, J.H., Lin, X.G., Zhu, J.G., Xiong, Z.Q., Xu, J., Cai, Z.C., Jia, Z.J., 2011. Autotrophic growth of nitrifying community in an agricultural soil. ISME J. 5, 1226-1236.

Yang, H.J., Li, Y., Wu, M.Y., Zhang, Z., Li, L.H., Wan, S.Q., 2011. Plant community responses to nitrogen addition and increased precipitation: the importance of water availability and species traits. Global Change Biol. 17, 29362944.

Yao, H.Y., Gao, Y.M., Nicol, G.W., Campbell, C.D., Prosser, J.I., Zhang, L.M., Han, W.Y., Singh, B.K., 2011. Links between ammonia oxidizer community structure, abundance and nitrification potential in acidic soils. Appl. Environ. Microbiol. 77, 4618-4625.

Ying, J.Y., Zhang, L.M., He, J.Z., 2010. Putative ammonia-oxidizing bacteria and archaea in an acidic red soil with different land utilization patterns. Environ. Microbiol. Rep. 2, 304-312.

Zavaleta, E.S., Shaw, M.R., Chiariello, N.R., Mooney, H.A., Field, C.B., 2003. Additive effects of simulated climate changes, elevated $\mathrm{CO}_{2}$, and nitrogen deposition on grassland diversity. PNAS 100, 7650-7654.

Zhang, L.M., Hu, H.W., Shen, J.P., He, J.Z., 2012. Ammonia-oxidizing archaea have more important role than ammonia-oxidizing bacteria in ammonia oxidation of strongly acidic soils. ISME J. 6, 1032-1045.

Zhang, L.M., Offre, P.R., He, J.Z., Verhamme, D.T., Nicol, G.W., Prosser, J.I., 2010. Autotrophic ammonia oxidation by soil thaumarchaea. PNAS 107, 17240-17245.

Zhang, Y., Zheng, L.X., Liu, X.J., Jickells, T., Capec, J.N., Gouldingd, K., Fangmeiere, A., Zhang, F.S., 2008. Evidence for organic $\mathrm{N}$ deposition and its anthropogenic sources in China. Atmos. Environ. 42, 1035-1041. 